\title{
Social Order in Sociology: Its Reality and Elusiveness
}

\author{
Sabo Suleiman Kurawa \\ Department of Sociology, Bayero University, Kano, Nigeria \\ Email: sabokurawa@yahoo.co.uk
}

Received April 24 $4^{\text {th }}$, 2011; revised September 28 ${ }^{\text {th }}$, 2011; accepted November $15^{\text {th }}, 2011$

\begin{abstract}
In the past, as well as in the present, depending on certain circumstances, sociologists tend to espouse one or the other of the contradictory answers proposed by political philosophers: social order is the result of some people being able to coerce others into obedience; or it rests on the general agreement among the members of the society; or it stems from their striking bargains with each other which are to every one's individual advantage as well as the collective advantage. I argue that it is unhelpful to consider these viewpoints as mutually exclusive categories. For the sociologist, social order must be a matter for empirical investigation. It is obvious that each of the above stated old philosophical views has its own grain of truth inherent in it, for each comes near to describing what is observed in some societies, or part of societies, of different types, at different periods of history, in particular situations or circumstances. But to consider each, as a "theory" of social order of universal validity, is to put it mildly unrealistic or absurd. To escape from this unrealistic approach which pervades some sociological discussions of social order it is pertinent to remember that social harmony is very often not achieved, and that social order and disorder are very much relative terms. I therefore posit that the actual state of relative order to disorder in a particular society or part of society is the outcome of complex forces of dependence and interdependence, of cooperation and conflict, of strength and weakness, of alliance and cleavage between people and groups. Thus, in this paper, a treatise is put forward, for the emergence of social order within the context of the theories of social integration and conflict in sociology. The essence is to describe how social order emanates under different circumstances with a view to analyzing its reality and elusiveness in daily social interactions in society. It appears that reality is in some sense Janus-faced (integration and conflict being the two unpropitious faces) and, despairing of ever encompassing both aspects in one theoretical framework. The big question is that: should the choice of reality be left to the whim of each sociologist?
\end{abstract}

Keywords: Social Order; Integration; Conflict; Reality; Elusiveness; Sociology

\section{Introduction}

It is rightly assumed that the central or salient issue of sociological theory is why there is order in society. Thus, it is necessary to sociology, as to any other discipline seeking to generate reliable and cumulative knowledge, that there be order in its subject matter. This means that only orderly, regular patterns can be discerned in social phenomena. It is only regularities which make possible description and explanation, in social sciences as much as in the natural sciences. Therefore, sociologists are expected to find order and regularity not only in stable societies and smoothly functioning organizations, but in bitter social conflict, in bloody uprisings, and in period of rapid, unplanned and superficially chaotic transformation. Needless to say law and order may breakdown in orderly regular ways. But order in this sense of regularity may be quite imperceptible to participants, and only apparent to sociologists faced with data on many similar situations as illustrated by Barton (1969) on communities plagued by natural calamities.

However this is not the sense of "order" in which "the problem of order" is said to be central or salient to sociological theory and it is significant that the two meanings be distinctively separated. What we refer, in sociology, by "the problem of order" is akin to the question(s) posed by Thomas Hobbes (1951): why do men cooperate with each other in society? Why is there not a continual "war of every one against everyone", as each individual pursues his own self-interest by whatever means, including force, at his disposal? Why is life, in consequence, "solitary, poor, nasty, brutish and short?” How, in other words, is a degree of harmony achieved? These questions can never be addressed and understood through the old political philosophy of social order arising from the coercing of people into obedience; or general consensus among people in a society; or striking bargains for individual and collective advantage. Contrary to these reasons, the question of understanding "social order" involves unraveling complex forces of dependence and interdependence, cooperation and conflict, strength and weakness, alliance and cleavage, etc. between people, groups or nations. Central to understanding these complex forces is based on our ability to appraise and comprehend the division of labour in societies.

\section{Division of Labour as Analogous to "Role Differentiation" and "Structural Differentiation"}

In a very old book, The Division of Labour, which has been regarded as one of the most celebrated of all discussions of the division of labour, Adam Smith (1970; orig., 1776) described the advantages of specialisation in human activities. Explaining further, Smith (1970: pp. 109-110) illustrated that with the pinmakers' shop where, in making each pin, about eighteen separate operations were involved in an interdependent, specialized form of relationship. He further indicated that where a single worker carrying out each and every operation-drawing and cutting 
the wire, sharpening the points, forming and attaching the head, etc.- -he could only make no more than twenty pins a day. Conversely, when ten men working together in one of the crude or archaic "manufactories" of Smith's period, each specializing in one or more operations, it was found that they could produce forty eight thousand pins a day. Thus, they could produce together at least two hundred and forty times as many pins a day in comparison to when they worked separately. Given this empirical finding it was not surprising that Smith considered the division of labor as a chief cause of "the wealth of nations", and that it has been carried forward in industrial societies without apparent limit.

It is noteworthy that the division of labour was not restricted only to economic activities. In sociological parlance, the terms "role differentiation" and "structural differentiation" signify sociology's recognition that increasing specialization of activities is not exclusively confined to the sphere of production.

The chief interest of the division of labour, on the part of the economist, is the vast multiplication of output of goods and services it provides. The sociologist, too, has not lost sight of the great incentives and possibilities associated with and accruing to specialization. It is however significant to note that even if the increased output is distributed very unequally, it is quiet likely that, in factual economic terms, everyone concerned will be better off in the end. However, for the problem of social order, increasing specialization as such is of less significance than its inevitable corollary: the growing web of interdependence which it spins through society. People's position in the division of labour both makes others dependent on them and simultaneously makes them dependent on others; it is a source both of power and limitation or constraint. The degree of power and dependence varies widely. On the one hand, everyone who performs some specialized task on which others depend has some resources for power. The resources are obvious in the case of the owner of a factory producing some general or basic necessity, especially if he has a degree of monopoly power in the product market and monopsony power in the labour market. However, they are at least obvious in the case of the unskilled labourer, whose labour power may be considered insignificant, when he may be readily replaced by someone else, particularly when he is not organized into a union of workers with some degree of monopoly of power.

On the other hand, in an industrial society, the overwhelming majority of the population directly produce for themselves no more than an infinitely small fraction of individual needs. Even the most powerful are dependent on countless others. Concomitant with an advancing division of labour, then, is a great lengthening of what may be called "chains of interdependence" (Elias, 1970) or "interaction chain length” (Blain, 1971; Kemper, 1972; Alias, 1998). Chains or networks of interdependence may include a few dozen people in a hunting and gathering band, or they may stretch across the world to hundreds of millions of people in contemporary society. Thus, the longer the chains of interdependence, the smaller will be the proportion anyone will know personally of those with whom he is interdependent. Contacts are more frequently indirect than direct and faceto-face. All this can be deciphered, albeit implicit, in such classical discussions of social solidarity as those of Toennies and Durkhiem (Blain, 1971). But their famous dichotomies between Gemeinschaft and Gesellschaft; and mechanical and organic solidarity; fruitful as they certainly have been, they however tend to distort our perception of what is essentially a continuous not a dichotomous variable. A proportion of relationships are indirect except in the very smallest of social units. We must be guided by this in relation with "consensus theory", on how social integration is achieved through the interplay of common norms and values.

\section{Consensual-Behavioural Relationship}

It is a seemingly undeniable fact that groups of people who interact with each other over a period of certain duration are likely to evolve normative regularities in their behaviour together. Some attempts were made to test empirically the plausibility of this assumption. The study which almost inevitably used to illustrate this is the Hawthorne "Bank-Wiring Group" (Roethlisberger \& Dickson, 1939), in which norms constraining the maximum output were observed to develop within the work-group apparently from fear of reductions in piece rates. A norm, in this sense, is plainly something more than an average; it is a standard of behaviour to which people adhere to a greater or lesser extent. But the question is: why do they adhere to them? There are answers to this question. Talcot Parsons (1951: p. 37) clearly recognized the two main possible reasons which answer the question. He reasoned that adherence arose due to: 1) conformity for the sake of expediency; and 2) conformity in response to moral commitment. Expediency better explains the behaviour of the bank-wiring group and many other cases, but having recognized the possibility of merely expedient conformity, Parsons virtually drops it from his work, subsequently. For Parsons, the great proponent of the consensual views of social order, moral commitment, to shared norms and values becomes an almost mystical element in social life. It is referred to as mystical because it is often difficult to see how his allembracing conception of the social order to be proven as either right or wrong.

Thus, for Parsons, social structure is made up of roles, norms, values, and collectivities (1961: p. 41). His model of dyadic interaction purportedly shows that in any continuing interaction, the actors must conform to each other's role expectations and establish stable cooperation. Norms and values are the buildingblocks for the huge edifice erected by Parsons to which his explanations of social structure are based. He is generally accused of having a shaky foundation as well as a problem of relativism (Sheida, 1988).

Parsons sees a norm as an element in the expectations of particular roles. Wherever there is "role-differentiation", norms "define the rights and obligations applicable to one role but not to another" (1961: p. 42). It is plausible that everyone may recognize and even accept the norms, but not everyone is bound by them because people occupy different roles. To recognize the norms defining the role of a farmer does not mean that everyone is expected to behave as a farmer. In contrast, values "are shared by the members over and above their particular roles". For instance, in a factory, the production engineer may be expected to concentrate on maintaining the quality and output of the products, the accountant to be concerned with keeping down unit costs, and the personnel manager to be in pursuit of the great virtue of establishing and upholding harmonious labour relations. These three role-specific norms may to a degree conflict with each other in specific circumstances. Yet each may be seen as a reflection of the engineer's, the accountant's and the personnel manager's shared commitment to the value of efficient production, and of their common goal of maintaining 
the survival and prosperity of their factory. The difference between a value and a goal, incidentally, is that between a mile post and a destination; the former is a general conception of the desirable, the latter a specific and desired situation. On collectivities, less need be said; if everyone in the factory shared the aforesaid values, it would be described as a collectivity. With his customary eloquence, Parsons defines a collectivity as a "system of ... interaction of a plurality of role performers ... normatively regulated in terms of common values and of norms sanctioned by these common values" (1961: p. 42).

The difference between norms and values is relative and it is a question of scope. What is a value at one level may be a norm at another. As Parsons sees it, "norms within one group of roles are legitimated by more general values which transcend these particular roles; but these values may themselves be relatively specific norms which are legitimated by still more general values at a higher level” (1961: p. 45). Thus, Parsons implicitly identifies religion as the top most value which holds the whole structure together.

Edward Shils, advocate of Parsons's position, has explicitly written on the 'central value system' of society which “... partakes of the nature of the sacred. In this sense, every society or its exponents and interpreters conceive of it, more or less correctly, as a secular, pluralistic and tolerant society" (Shils, 1961: p. 117). The central value system consists of the values and standards espoused and more or less observed by those in authority and it always legitimates the existing distribution of roles and rewards. It rests on the need which human beings have for incorporation into something which transcends and transfigures their concrete individual existence (Shils, 1961: p. 121). However, Shills does not suggest that every member of any society subscribes to the central values. Rather there is a minimum level of acceptance of authority in society, which presumably disintegrates if the minimum is not met.

It is a mistake to dismiss consensus out of hand as a factor which, in many circumstances, promotes social integration. Yet it is a difficult task to investigate the beliefs which people actually hold and which guide their actions. In consequence, the claims made by Parsons and his followers for the unifying power of shared values often seem too sweeping and empirically ill-founded. Alvin Gouldner pointed out that: "Parsons never allows moral values to become just one other variable in the social equation. Paradoxically, however, neither does he ever mount a full-scale and systematic exploration of the nature and functioning of moral values” (Gouldner, 1971: p. 140).

For as soon as attention is turned to the practicalities of social life, numerous difficulties to any solution of the "problem of order" exclusively in terms of value integration become obvious as follows:

Firstly, it is implicit in Parsons's view of a hierarchy of norms and values of ever-increasing generality that the topmost and most widely spread are also the most abstract, vague and unspecific. They can therefore be used to legitimate any social structure and none in particular. Parsons himself notes (1951: p. 293) that revolutionaries appeal to the same abstractions of "democracy" and "justice" as do the upholders of the status quo. He chooses to interpret this as evidence that the overt conflict is the top tenth, so to speak, of an ice berg of underlying unity; but it might as easily be taken as evidence of the inability of common commitment to abstract ideas to maintain social cohesion.

Secondly, a related point, in many particular situations two or more general values may conflict with each other. Lipset (1964) identifies "achievement” and "equality” as two key variables or values in the American credo; but as often as not, opportunities for "achievement" mean competition for unequal rewards. Mann (1970) points out that, in such circumstances, it is likely that "cohesion results precisely because there is no common commitment to core values” Mann (1970: p. 424). Thus, less privileged groups may be more tolerant of inequality just because they are less committed to achievement.

Thirdly, "negative consensus" may contribute more to social cohesion than "positive consensus". Douglas (1970) emphasizes the significance of "accommodative morality" in complex, pluralistic societies. The diversity of tastes and commitments which abounds in pluralistic societies is facilitated by a general value of privacy-embodied in the privacy of the home, numerous private clubs and associations and in the anonymity of the city.

Fourthly, it should not be too readily assumed that consensus on values promotes social harmony irrespective of the content of the values. As Van den Bergh pointed out, "consensus on norms such as extreme competition and individualistic laissezfaire, or suspiciousness and treachery..., or malevolence and resort to witchcraft is hardly conducive to social solidarity and integration” (1963: p. 87).

Fifthly, does consensus need to be about the central institutions of society? There is abundant evidence that only small minorities can give expressions to a reasonably articulate set of beliefs about social institutions (Converse, 1964), yet it tends to be assumed that even the inarticulate have absorbed the general values. Thus, quite complex patterns of social interaction may continue, not because participants share any specific values concerning the broad organization of society, but because their relations are pervaded by less ethereal feelings like trust, and because everyone gets something out of their mundane relationships. The significance of trust between parties to exchange relationships has long been recognized. Systems of ceremonial exchange were discussed by Malinowski (1944) and Mauss (1954) among others, serve to generate trust and alliances, which promote social understanding and cohesion as well as trade in commodities. How then does social exchange start? Gouldner (1960) suggested that the norm of reciprocity (treat others as you would like them to treat you) is a culturally universal phenomenon and acts as a starting-mechanism for social transactions. Such a norm may indeed, be found in every society, but as Blau (1964: p. 92) comments, moral commitment to it probably only reinforces tendencies which stem from the very logic of interdependence. For, where people are interdependent with one another, it is merely prudential and expedient behaviour to follow the principle of reciprocity, no matter what one's moral feelings are. This is not to deny the fact that every culture contains countless standards as to what constitutes fair exchange in particular situations. It is significant to note that, in extending his theory of social exchange from face-to-face bargaining to the level of macro-structures, Blau finds it necessary, like Parsons and others, to posit commitment to more general values which promote understanding and the establishment of social order.

\section{Conflictual-Behavioural Relationship}

Conflict is an ubiquitous phenomenon. Thus, if agreement of one sort and another is found in every society, so is conflict. 
Coser (1956), building very directly on the work of Simmel (1955, orig., 1908), has done a great deal to overcome the hitherto common assumption that conflict is necessarily something destructive or pathological. Perhaps he went too far and painted too rosy a picture of the consequences of conflict. For it must not be denied that conflict often creates chaos out of order. History documents how conflict within and between societies can destroy complex organization, reverse the division of labour and reduce standards of living. Yet conflict takes many forms and has many consequences; it is certainly absurd to see consensus and conflict simply as opposites. Cooley (1918: p. 39) puts the matter in a nutshell when he observed that "conflict and cooperation are not separable things, but phases of the process which always involves something of both" the same scarce resources which require cooperation to produce become as often the focus of conflict over how they shall be distributed as rewards among those who helped to produce them. Then again, the very experience of close cooperation can set up tensions between the cooperating individuals and groups.

It is noteworthy that conflict is rarely unlimited. Some measure of agreement is usually evident even between antagonists. There is generally at least a minimal consensus on the "rules of the game", on the means which shall and shall not be used in the conflict. For instance, in pressing for a wage claim, by workers in an industry, a strike is accepted as a legitimate means of effecting the outcomes, while slapping or shooting the supervisor or the manager is not, even wars do usually proceed on some ground rules. As Simmel emphasized, conflict is a relationship between opponents.

Conflict may or may not be accompanied by hostility and animosity between the parties to it. Where conflict is the expression of emotional hostility, it becomes an end in itself. Hostility may, perhaps, be directed impersonally against all members of a minority group, but intimate personal relationships are particularly likely to give rise to violent hostility. On the other hand, where conflict is pursued as a means to an end-as a trial of strength over the allocation of resources, for example-it is possible that the parties may feel little bitterness towards each other. Much depends on how the parties define the situations. Ideology may intensify conflict by representing it in terms not of personal or sectional interests, but of broad ethical principles. Then again, it may render the conflict less bitter and hateful. When opponents are seen only as prisoners of social situations, they ought scarcely to be hated so much.

It is not a simple matter to generalize about the consequences of conflict, either within groups and organizations or between them. Conflict within groups may destroy them as units capable of collective actions or it may actually assist them. A family row may clear the air and a strike may, on occasion, be settled to the satisfaction of both parties. On the other hand, families do break up, and strikes often end in greater discontent and lower productivity than when they started. Conflict is more likely to serve as a safety valve or to resolve clashes of interest when there is already an underlying unity present. The more secure the matrix of agreement within which conflict takes place, the more internal conflict the group may be able to absorb. Paradoxically, then, the correlation between consensus and conflict may be positive, not negative (Coser, 1956: p. 81). Thus a well integrated organization may be able to encourage internal conflict as a source of ideas which can be put to fruitful use. But again much depends on the type of organization. What may be true of say an advertising agency, is not necessarily true of a religious or political sect. The latter often show monolithic agreement, but they typically cannot tolerate much internal conflict. They require unanimity and total involvement of their members, so that when disputes break out on outwardly trivial points of dogma, they can be extremely bitter and the outcome may be a sudden and violent division of the group.

Conflict within groups are related in complex ways. First of all, conflict, and even just passive hostility between groups, serves to define group boundaries and makes it clear who is one of "us" or who is one of "them".

Membership of "in groups" and "out groups" is not always at all clear cut. In open pluralistic structures, an individual is a member of many groups. This not only means that he is less likely to be totally involved as a personality in any one of them, but that he will participate in a variety of inter group conflicts, the lines of which cross cut each other. As a result, people who are antagonists in one conflict are allies in another. The "web of group affiliations” as Simmels translator so aptly phrased it, thus serves to moderate the intensity of conflicts. An off- shoot of this idea is the notion of cross-pressures. It has often been suggested that individuals who belong to two or more groups which pull their loyalties in contrary directions react by feeling less intensely about the issue in question.

According to circumstances, conflict between groups may promote social cohesion or disruption; internal conflict may create schism or be a sign of basic unity; ideology may intensify conflict or reduce it.

\section{Structure of Conflict}

Some of sociology's most exciting propositions have, however, been very much concerned with not only the form but also the content of consensus and conflict in historical societies. In this, Marx and Weber, and other writers in their traditions, offer a marked contrast to Simmel on issues particularly dealing with group interests and group consciousness within the context of the structure of conflict.

\section{Marxian Notion}

Marx and his works generally tended to generate a lot of controversy. Hence any brief statement is bound to be disputed by someone. With that caution; we view Marx as one of the greatest writers on social conflict. Yet he was equally concerned with the conditions which promote consensus as those which lead to conflict. It is true that he saw little prospect of society wide harmony, except in the communist society of the future. But he was much concerned with the circumstances in which men in similar social situations would recognize their common interests and unite in groups capable of collective action in pursuit of their interests.

The material bases of a society-its modes of production and economic organization-generate a finite number of social groupings, the members of each of which share a similar social situation and therefore have common interests. These groupings, however, are mere categories-Dahrendorf (1959) was later to call them "quasi-groups"-and their members are by no means necessarily conscious of their common situation and interests. There may, therefore, be considerable conflict between segments of the same grouping. Marx asked how social categories could become conscious of a common identity and unite against other groups. 
Marx was, however, not so much interested in the formal and abstract process as in the particular case of the genesis and dynamics of capitalist society. The structure of interests changed during its growth. Hence, Marx did not have a romantic utopian image of the past; he saw that the proletarian and bourgeois classes had a common interest in the overthrow of the remnants of feudalism, and wrote glowingly of the vigour with which the bourgeois entrepreneurs transformed the economy (Marx \& Engels, 1968). As industrialization proceeded, however, the interests of the two classes came to be at odds. The workers might fail to perceive this, and retain a false conception of their true interests, but economic forces gradually drew them into conflict with the bourgeois. In the early capitalist economy, many groups persisted whose class affiliation was ambiguous, the artisan whose special skills were in short supply, the selfemployed craftsman, the small factory-owner who worked alongside his men. Marx predicted the increasing polarisation of society into two camps. The petty bourgeois would disappear, particularly when prosperity would be making him a true bourgeois, or lack of it would make him to be a wage-slave; with him would disappear the ambiguities of interest and the crosscutting ties between the classes. The reason(s) for such a happening, as argued by Marx, was essentially economic. The logic of machine production and economies of scale would dictate larger and larger productive units, driving out the self-employed craftsman and the small factory owner (if he did not himself expand). Machines would also make many hitherto scarce skills redundant, and make men into unskilled machine minders. Thus, with labour increasingly being homogeneous, its strength in the market would decrease. The reserve army of the unemployed, any member of which could do a job as well as the unskilled labour then in employment, would bid down wage rates, leading to mass pauperization. Furthermore, Marx accepted the view of the competitive process advanced by Ricardo and the English classical economists. Competition between entrepreneurs would be so fierce that profit margins would leave little room for the indulgence of humanitarian delusions; an employer who paid more than the market wage would soon be driven into bankruptcy. However, the 20th century economists have suggested that the growth of economic units and the emergence of oligopolistic markets make such strict market discipline unlikely or untenable.

Suffering itself would assist for the emergence of class consciousness, and make evident the advantages of solidarity, of collective action to multiply the industrial bargaining power of the workers, and eventually to overthrow the capitalist system. Militancy would be especially likely to emerge, for example, in mining and other extracting industries, where the workers share a common lot in a homogeneous community. In contrast, difficulties of communication would prevent the emergence of the peasantry, who are scattered across the countryside, as a selfconscious class (Marx \& Engels, 1968: pp. 171-172). The extent to which external leadership is necessary to catalyze classconsciousness has long been in dispute between Marxists such as Lenin and Rosa Luxemburg. Marx, however, firmly predicted increasing organization along class lines for collective action, at first in trade unions for industrial objectives, later broadening to concerted political action for the overthrow of capitalism.

It is argued that Marx's prognostications have not all proved to be as accurate as expected. For instance, why have the lines of conflict in capitalist society not become deeper and more clear-cut? The answer seems to lie partly in social developments which Marx did not entirely foresee, but also partly in theoretical difficulties in the notion of objective class interests.

\section{Weberian Approach}

Many of Weber's differences with Marx centre on the notion of interests. Certainly the sociologist may observe that a category of people share a common situation in some respect. But can such people be said to have objective interests as a group, interests which they may or may not perceive "correctly"? Weber was extremely sceptical about the validity of any definition of individual or group interests except as they appeared to the individuals themselves.

Though Weber did not by any means reject all of Marx's analysis of class, he saw nothing inevitable in the emergence of class consciousness and collective class action. A category of people could be said to have a common class position insofar as the life chances of its members were determined by their similar position in the market (Weber, 1968).

The common situation may not be recognized at all. Or it may produce nothing more than similar individual reactions, taking the form of low morale, unorganized and perhaps semiconscious go-slow, or at most, sporadic individual acts of sabotage.

Since Weber did not suppose there were only two class situations in society-the market would continue to differentiate the life chances of those with different kinds of property and various kinds of skills-he saw little reason why causes and consequences of life chances should necessarily become more transparent in explaining class situation.

Furthermore, Weber recognized that the common economic situations were not the only bases for collective social action. Categories of people who shared a common status, religion, ethnic background or political outlook could also enter as units in social conflict. Of particular interest were people who shared a common "status situation".

Sharing a common "style of life", status-groups are normally conscious of their common status situation. Status distinctions are, of course, most often correlated with economic inequality, but "the notion of honor peculiar to status absolutely abhors that which is essential to the market: hard bargaining" (Weber, 1968: p. 937). The question here is, which principle gets the upper hand? Weber suggests that, when there is little economic change and a stable pattern of allocation, status-groups will tend to form and tend to impede the development of free markets. Where the economy is rapidly changing (and this can stem from the impact of change from outside the society), status will tend to be undermined by market and class be more prominent as a basis for social action. In relatively stable situations, various power resources (economic, honorific, political-organizational, etc.), are probably distributed in much the same way; in periods of rapid transition their distribution may be discrepant, with economically powerful perhaps not being accorded high status.

\section{Changing Trends after Marx}

Weber's discussion suggests reasons why patterns of social conflict have remained more complex than Marx expected; there have also been a number of specific social trends which have, so far, frustrated Marx's predictions. They fall into three 
groups, as follows:

Firstly, there have been several developments in industrial economies which have tended to fragment and diversify the distribution of interests and, it is argued, to create more quasigroups rather than fewer. Though it is true that, in some industries, technology has reduced the worker to an unskilled machine minder, the broader trend of the division of labour has been to make labour more heterogeneous rather than homogeneous. This is the trend which Dahrendorf (1959: p. 48) referred to as "the decomposition of labour". More workers have skills which cannot quickly be learned, so they cannot easily be replaced and are able to command high wages. Even relatively unskilled groups may occupy strategic points or positions in the division of labour that, if well organized, they have immense bargaining power. In short, there are many groups of employees who have an advantageous position in the labour market, and this differentiation does not facilitate class solidarity.

A related development has been the emergence of the "new middle class" - the salaried occupations ranging from high bureaucrats to lowly clerks. They now form a much larger proportion of the labour force than in Marx's day, and in some technologically most advanced industries actually outnumber the manual workers. Some of them earn less than some manual workers, others much more. In such a situation, to which class do they belong? If they earn their living entirely by selling their labour they might be considered objectively as "working class". But we know that this fails to coincide with the subjective identification of most of them. Lockwood (1958), and Sabaz (2010) made an obvious point that the "work situation" of particular groups the "significant others" they encounter in their work, tend to influence their group identification. For instance, we should not expect domestic servants to form a hotbed of militancy and radicalism.

On the other hand, at the opposite side of the market there has been a corresponding "decomposition of capital" (Dahrendorf, 1959: p. 41).This is the frequently discussed phenomenon of "separation of ownership and control" which has occurred since Marx's day, made possible by the spread of the JointStock, Limited Liability Company. Economic units have become larger, yet their ownership has become more dispersed through share holdings, while practical control has passed to salaried bureaucrats. The literature in sociology and economics on the extent of this development and its implications for economic motivation and social relations can be sought from Nichols, (1969) and Wallace, (2009). From his own viewpoint, Dahrendorf argued that Marx's conception of ownership and non-ownership of capital as the great divide in society was excessively legalistic. What is now important, said Dahrendorf is not whether people legally own capital, but their relationship to authenticity and control. In any "imperatively co-ordinated association", there was a "command class". Hence, it is not clear how, in a multi-tier chain of command, one decides the zero-point dividing those in authority from those in subordination. Thus, within a complex division of labour, few people escape a considerable degree of constraint. In any case, Dahrendorf's view would give a much weaker prediction about the lines of conflict in society as a whole than did Marx's. Since, in a pluralistic society, a man may belong to many groups, being in authority in one and taking orders in another, the "theory" gives no guidance as to whether certain lines of conflict will become more salient than others, or how groups will coalesce in alliances for common objectives.
Secondly, many factors have impeded the crystallisation of quasi-groups as self-conscious entities capable of collective action in conflict with others. A sense of society-wide consensus, even if it be only a limited sense of common membership in one society, is said to impede the emergence of full class consciousness. Marshall (1950) traced the growth of what he called rights of citizenship in Britain from the 17th century. "Civil" rights of citizenship-equality before the law-were followed by the gradual extension of political rights to all adults, and later by "social” rights of citizenship as embodied in the provisions of the welfare state. As a whole, it is argued, this process has achieved the "civic reincorporation" of the working classes, who no longer feel themselves "outside" a system which exists for the benefit of others. Associated with this tendency (whether as cause, effect, or both) has been the increasing institutionalization of class conflict. Lipset (1960) speaks of "the democratic class struggle", and Dahrendorf remarks that:

"Instead of a battlefield, the scene of group conflict has become a kind of market in which relatively autonomous forces contend according to certain rules of the game, by virtue of which nobody is a permanent winner or loser” (Dahrendorf, 1959: p. 67).

Free collective bargaining illustrates this par excellence, and serves, on the whole, to prevent industrial conflict spilling over into the serious political conflict which Marx predicted. As governments in the United States, Britain and elsewhere have, for macroeconomic reasons, increasingly intervened in collective bargaining, it remains to be seen whether or not the insulation of spheres of conflict is a long term phenomenon. Affluence, too, has often been said to dampen down discontent and discourage class conflict, though, as Goldthorpe, Lockwood, et al. (1969) have argued at length, the relationship between economic prosperity and political outlook is far from being simple.

Thirdly, individual social mobility is a factor which may, in some ways, be seen as an alternative to inter-group conflict. Seeking to explain why there was no strong socialist political party in the United States, Sombart suggested, as early as 1906 that abundant opportunities for individuals to make good-to use the system-would reduce demands for changing the system. Dahrendorf goes further and suggests that "individual competition and collective action are in principle mutually convertible, that they are basically equivalent expressions of the same great social force, contest” (Dahrendorf, 1967: p. 19). In other words, the individual discontented with his lot can, in an open and pluralistic society, strive with some hope of success to change his situation by individual effort(s). However, inequalities of many kinds restrict most individuals' chances of realising their interests alone, and therefore there are, even in the most open societies, probably limits to the extent to which individual mobility can supplant collective action in groups. Hence social order is sometimes being viewed as a reality or as an elusive phenomenon. It can therefore not be seen as exclusively only present in social integration or only an inclusive category in social conflict.

\section{Conclusion}

It is illustrated that, if sociologists remain interested in "social order" as a general problem, it is because they are salvaging particular insights from old systems and subjecting them to relatively modest empirical tests. Hence, the big, bold, tradi- 
tional and ideologically charged "theories" of social integration and conflict increasingly appear like dinosaurs ill adapted to the complexity of contemporary societies. They however retain their emotional appeal, and there is a note both of satisfaction and regret in Dahrendorf's conclusion that "the social structure of interests no longer guides us directly to the parties and platforms of political conflicts; interests seem to get 'lost', or perhaps satisfied, before they ever appear in the area of group antagonism”, (Dahrendorf, 1967: pp. 14-15). The Parsonian concern with the social structure of values is no more adequate. It is therefore likely to prove more fruitful to formulate welldefined propositions of limited scope, identifying what factors, present in what strengths and combinations tend to change the level of consensus or conflict; harmony and disharmony or stability and instability divides. Hence, I wish to finally state that the debates between "consensus" and "conflict" views of society cannot be settled in the realms of "theory", for it is essentially an empirical question whether a society, of a particular type and in a particular time and at a particular situation will show a high level of conflict or consensus. The primary concern is to illustrate the relevance of "theory" to an empirical research, in sociology.

\section{REFERENCES}

Alias, W. T. (1998). Understanding social interactions. London: Crooke.

Barton, A. H. (1969). Communities in disaster, double day. New York: Garden City.

Berghe, P. L. V. (1963). Dialetic and functionalism: Toward a theoretical synthesis. American Sociological Review, 25, 695-705. doi:10.2307/2089908

Blain, R. R. (1971). An alternative to parson's four-function paradigm as a basis for developing general sociological theory. American Sociological Review, 36, 678-692. doi:10.2307/2093598

Blau, P. M. (1964). Exchange and power in social life. New York: Wiley Press.

Converse, P. E. (1964). The nature of belief in mass publics. In D. E. Apter (Ed.), Ideology and discontent (pp. 206-261). Glencoe, IL: Free Press.

Cooley, C. H. (1918). Social process. New York: Scribners.

Coser, L. A. (1956). The functions of social conflict. London: Routledge and Kegan Paul.

Dahrendorf, R. (1959) Class and class conflict in industrial society. Stanford, CA: Stanford University Press.

Dahrendorf, R. (1967). Conflict after class: New perspectives on the theory of social and political conflict. London: Logmans.
Douglas, J. D. (1970). Deviance and order in a pluralistic society. In J. C. Mickney, \& E. A. Tiryakian (Eds.), Theoretical sociology (pp. 368-401). New York: Appleton-Century-Croft.

Elias, N. (1970). What is sociology? London: Hutchinson.

Goldthorpe, J. H., Lockwood, D., Bechhofer, F., \& Platt, J. (1969). The affluent worker in the class structure. Cambridge: Cambridge University Press.

Gouldner, A. W. (1960). The norm of reciprocity. American Sociological Review, 25, 161-178. doi:10.2307/2092623

Gouldner, A. W. (1971). The coming crises of western sociology. London: Heine Mann.

Hobbes, T. (1651). Leviathan. London: Crooke.

Kemper, T. D. (1972). The division of labour: A post-durkheimian analytical view. American Sociological Review, 3, 739-753. doi: $10.2307 / 2093584$

Lipset, S. M. (1960). Political man. London: Heinemann.

Lipset, S. M. (1964). The first new nation. London: Heinemann.

Lockwood, D. (1958). The black coated worker. London: George Allen and Unwin.

Malinowski, B. (1944). A scientific theory of culture. Chapel: University of North Carolina Press.

Mann, M. (1970). The sociological cohesion of liberal democracy. American Sociological Review, 35, 423-439. doi:10.2307/2092986

Marshall, T. H. (1950). Citizenship and social class and other essays. Cambridge: Cambridge University Press.

Marx, K., \& Engels, F. (1968). Selected works. London: Lawrence of Wishant.

Mauss, M. (1954). The gift. London: Cohen and West.

Nicholis, T. (1969). Ownership, control and ideology. London: George Allen and Unwin.

Parsons, T. (1951). The social system. New York: Free Press.

Parsons, T. (1951). An outline of the social system. In T. Parsons, E. A. Shills, K. D. Naegele, \& J. R. Petts (Eds.), Theories of society (pp. 30-79). New York: Free Press.

Roethlisberger, F. J., \& Dickson, W. J. (1939). Management and the worker. Cambridge: Harvard University Press.

Sabaz, K. (2010). Social interaction and group solidarity. India: Elva Press.

Sheila, R. M. (1998). Normative behaviour: An analytical framework. New York: Free Press.

Shills, E. A. (1961). Centre and periphery. In The logic of personal knowledge: Essays presented to michael polanyo (pp. 117-130). London: Routledge and Kegan Paul.

Wallace, S. (2009). The socio-economic relationship of labour and labour power. Uganda: The William Press,.

Weber, M. (1968, org. 1922). Economy and society. New York: Bedminster. 